\title{
Contents Vol.7, 1997
}

Official Journal of the European Stroke Council

\section{Ccrcbrovasculai Diseases}

\section{Editors-in-Chief}

J. Bogousslavsky, Lausanne M.G. Hennerici, Mannheim

Associate Editor

J.D. Easton, Providence, R.L 


\section{Editorial Board}

M.G. Bousser, Paris

L.R. Caplan, Boston, Mass.

M. Fisher, Worcester, Mass.

J. van Gijn, Utrecht

P.J. Koudstaal, Rotterdam

W. Kuschinsky, Heidelberg

J.-L. Mas, Paris 
J.W. Norris, Toronto

B. Norrving, Lund

T. Sawada, Osaka

C.P. Warlow, Edinburgh

S.G. Waxman, New Haven, Conn.

H. Zeumer, Hamburg

\section{Advisory Board}

H. Adams, Iowa City, Iowa

F. Aichner, Innsbruck

P. Amarenco, Paris

K. Asplund, Umea

J.-C. Baron, Caen

G. Boysen, Hvidovre

J.C.M. Brust, New York, N.Y.

L. Candelise, Milan

R. Cote, Montreal

P. Dalai, Bombay

S. Davis, Parkville, Vic.

GJ. Del Zoppo, La Jolla, Calif.

JJLDe Reuck, Gent

E. Diez-Tejedor, Madrid

G.A. Donnan, Melbourne

J.M. Ferro, Lisbon

M.D. Ginsberg, Miami, Fla.

D.I. Graham, Glasgow

J. Grotta, Houston, Tex.

W. Hacke, Heidelberg

G J. Hankey, Perth

W.-D. Heiss, Cologne 
M. Hommel, Grenoble

D. Inzitari, Florence

K.R. Lees, Glasgow

G.L. Lenzi, Rome

S.R. Levine, Detroit, Mich.

D. Leys, Lille

J.L. Marti-Vilalta, Barcelona

H. Mattle, Berne

J.P. Mohr, New York, N.Y.

M.E. Moseley, Stanford, Calif.

M.A. Moskowitz,

Charlestown, Mass. J.-M. Orgogozo, Bordeaux

F. Regli, Lausanne

D. Russell, Oslo

W. Sandmann, Dusseldorf H. Schafer, Marburg

A. Schwartz, Mannheim

J. Theron, Caen

G. van Melle, Lausanne

N.G. Wahlgren, Stockholm

B. Weir, Chicago, IU. 
Contents Vol, 7, 1997

Cerebrovascular Diseases

No. 1 
No. 2

1 Message from the Editors

Review

2 Stroke and Epilepsy: Critical Review of the Literature.

Part II: Risk Factors, Pathophysiology and Overlap Syndromes Pohlmann-Eden, B. (Mannheim/Boston, Mass.); Cochius, J.I.; Hoch, D.B, (Boston, Mass.); Hennerici, M.G. (Mannheim)

\section{Original Papers}

10 Changes in Serum Lipid Measurements following Acute Ischaemic Stroke

Butterworth, RJ.; Marshall, W.J.; Bath, P.M.W. (London)

14 Full Range of Vasodilation Tested by Transcranial Doppler In the Differential Diagnosis of Vascular and Alzheimer Types of Dementia

Marcos, A.; Egido, J.A.; Barquero, M.; Fernandez, C; Varefa de Seijas, E.

(Madrid)

19 How Reliable Are Simple Questions in Assessing Outcome alter Stroke?

Dennis, M.; Wellwood, I.; O'Rourke, S.; MacHale, S.; Warlow, Ch. (Edinburgh)

22 Are Simple Questions a Valid Measure of Outcome after Stroke? Dennis, M.; Wellwood, I.; Warlow, Ch. (Edinburgh)

28 Dalteparin in Acute Ischemic Cerebrovascular Disease:

A Safety Study

Dahl, T. (Oslo); Frfis, P. (Kristiansand); Abildgaard, U. (Oslo)

34 After Successful Endarterectomy for Symptomatic Carotid Stenosis, Should Any Contralateral but Asymptomatic Carotid Stenosis Be Operated on as Well?

Dippel, D.WJ.; Koudstaal, PJ.; van Urk, H.; ffibbema, J.D.F. (Rotterdam); ^\&l3ijn, J. (Utrecht); Slattery. J.; Rothwell, P.M.; Warlow, C.P. (Edinburgh) on behalf of the European Carotid Surgery Trialists* Collaborative Group

43 Positron Emission Tomographic Study of Contralateral Hemispheric Hypometabolism in Middle Cerebral Artery Infarction

De Reuck, J; Decoo, D.; Jansen, H.; Santens, P.; Strijckmans, K.; Goethals, P.; Lemahieu, I. (Ghent)

48 Risk of Dementia after a First-Ever Ischemic Stroke: A 3-Year Longitudinal Study Treves, T.A.; Aronovich, B.D.; Bomstein, N.M4 Korczyn, A.D. (Tel Aviv)

Letters to the Editor 
57 Transcranial Color-Coded Duplex Sonography in Arterial Cerebrovascular Disease

Baumgartner, R.W.; Mattle, H.P. (Bern); Aaslid, R. (Seattle, Wash.); Kaps, M. (Lttbeck)

\section{Original Papers}

64 Body Temperature and Fibrinogen Are Related to Early Neurological Deterioration in Acute Ischemic Stroke

Davalos, A. (Girona); Castillo, J.; Pumar, J.M.; Noya, M. (Santiago de Compostela)

70 Enhanced Red Blood Cell Aggregation Unrelated to

Fibrinogen: A Possible Stroke Mechanism in Young Patients Faber, C.G.; Troost, J. (Maastricht); Vermes, I. (Enschede); Lodder, J. (Maastricht);

Kalsbeek-Batenburg, E.M. (Enschede); Kessels, F. (Maastricht); Haanen, C. (Enschede)

77 The Role of Standardised Assessments in Comparing Stroke Unit Rehabilitation

Kalra, L. (Orpington); Potter, J.; Patel, M.; McCormack, P.; Swift, C.G. (London)

85 Prediction of Long-Term Outcome after Primary Intracerebral Haemorrhage: The Importance of the Site of Lesion

Beldman, T.F.J.; Rinkel, G.J.E.; Algra, A, (Utrecht)

89 An Observation on the Time of Hospital Arrival and Correct Diagnosis with CT in Acute Cerebral Stroke Patients

Wang, X.; Guo, H.; Zhang, X.; Zhu, H.; Li, Y.; Zhou, G. (Beijing)

94 Thrombolysis in the Vertebrobasilar Circulation: The Australian Urokinase Stroke Trial. A Pilot Study Mitchell, PJ.; Gerraty, R.P.; Donnan, G.A.; Fitt, G.; Tress, B.M.; Thomson, K.R.; Davis, S.M. (Melbourne)

100 The Feasibility of a Collaborative Double-Blind Study Using an Anticoagulant

The WARSS, APASS, PICSS, HAS and GENESIS Study Groups (New York, N.Y./Detroit, Mich./Boston, Mass./Buffalo, N.Y.)

\section{Special Article}

113 Optimizing Intensive Care in Stroke: A European Perspective.

A Report of an Ad Hoc Consensus Group Meeting The European Ad Hoc Consensus Group

\section{Stroke Vignette 128 Announcement}

53 Hallucinosis and Thalamic Infarcts

Neau, J.-Ph.; Rosier, M.-P.; Bailbe, M.; Fabre, C; Vandermaicq, P. (Poitiers); Vignon, J.-J. (Chateauroux); Gil, R. (Poitien)

55 Claude's Syndrome Associated with Sensory Loss

Toyoda, K,; Saku, Y. (Kurume); Ibayashi, S.; Fujishima, M. (Fukuoka)

\section{KARGEK}

E-Mail karger@karger.ch Fax+4161 3061234 http://www.karger.ch 


\section{(c) 1997 S. KargerAG, Basel}

The list of contents is available at: http:ZAvww.karger.ch/joumaIs/cdycdicontJitm 
No. 3 
No. 4

Issues In Stroke

129 Cognitive Correlates of Leukoaraiosis Easton, J.D. (Providence, R.I.)

Original Papers

138 Frequency and Degree of Carotid Stenosis in Small Centrum Ovale Infarcts as Compared to Lacunar Infarcts Boiten, J.; Rothwell, P.M.; Slattery, J.; Warlow, C.P. (Edinburgh)

144 Diabetes, Hypertension and Erythrocyte Aggregation in Acute Stroke Beamer, N.; Giraud, G.; dark, W.; Wynn, M.; Coull, B. (Portland, Oreg.)

150 Pulsatile Tinnitus of Venous Origin as a Symptom of Dural Sinus Thrombosis. Case Report and Review of the Literature Utz, N.; Mull, M.; Kosinski, C; Thron, A. (Aachen)

154 Stroke Registry of Tartu, Estonia, from 1991 through 1993

K6rv, J.; Roose, M.; Kaasik, A.-E. (Tartu)

163 Assessment of Costs Related to Hospitalization of Stroke

Patients in Austria for 1992 and Prospective Costs for the Year

2010

Haidinger, G.; Waldhoer, T. (Vienna); Tuomilehto, J. (Vienna/Helsinki);

Vutuc, C. (Vienna)

168 Stroke Rehabilitation - Discharge Predictors

LSfgren, B.; Nyberg, L.; Osterlind, P.-O.; Mattsson, M.; Gustafson, Y. (Ume5)

\section{Case Reports}

175 Head Tremor and Stroke

Kim, J.S. (Seoul) 180 Ischemic Stroke Due to Left Internal Carotid Occlusion in a

Patient with Thrombocytosis following Splenectomy

Del Sette, M.; Solaro, C; Conti, M.; Gandolfo, C. (Genova)

\section{Letter to the Editor}

183 Ataxic Hemiparesis Caused by Infarction of the Cerebral Peduncle

Luijckx. G.-J.; Spaans, F.; Boiten, J.; Lodder, J. (Maastricht)

\section{Correspondence}

185 Microembolic Watershed Infarction Complicating Carotid Endarterectomy

Levi, C.R.; Bladin, C.F.; Chambers, B.C.; Royle, J.P.; Donnan, G.A. (Heidelberg, Vic.)

182 Stroke Vignette 


\section{Original Papers}

187 Reorganization of the Executive Motor System after Stroke

Dettmers, C (London/Jena); Stephan, K.M. (London/DUsseldorf); Lemon, R.N.; Frackowiak, R.SJ. (London)

201 Does Carotid Endarterectomy Modify Cerebral Vasomotor Reactivity?

Borastein, N.M.; Gur, A.Y.; Shifiin, E.G.; Morag, B A, (Tel Av£\$

205 What Is the Correct Management of Blood Pressure In Acute

Stroke? The Blood Pressure in Acute Stroke Collaboration

Bath, F.J.; Bath, P.M.W. (London) 214 A Comparison of Beat-to-Beat Blood Pressure Variability in

Acute and Subacute Stroke Patients with Cerebral Infarction

Robinson, T.; Ward-Close, S.; Potter, J. (Leicester) 220 Nausea and Vomiting in Acute Ischemic Stroke

CanhSo, P.; Melo, T.P.; Salgado, A.V.; Oliveira, V.; Pinto, A.N.; Crespo, M.;

Ferro, J.M. (Lisboa)

\section{Case Reports}

226 Microsurgical Embolectomy and Removal of a Migrated Coil from the Middle Cerebral Artery Spetzger, U.; Reul, J.; Thron, A. (Aachen); Wamke, J.P. (Zwickau);

Gilsbach. J.M. (Aachen)

232 Cerebral Infarction Due to External Carotid Artery Atherosclerosis

I ngall, TJ. (Scottsdale, Ariz.)

235 Course of Vasomotor Reactivity Using Dynamic Susceptibility Contrast-Enhanced MRI in a Patient with High-Grade Internal Carotid Artery Stenosis: Pre- and Post-Surgical Findings

Berthezene, Y.; Nighoghossian, N.; Meyer, EUDamien, J.; Cinotti, L.; Adeleine, P.; TrouUlas, P.; Froment, J.C. (Lyon)

239 Cardiac Myxoma and Intracerebral Hemorrhage

Schalhalter-Zoppoth, I.; Fazekas, F.; Kapeller, P.; Lechner. A.; Rigler, B.; Offenbacher, H. (Graz)

\section{Correspondence}

242 'Are These Drugs Really Equally Effective?'

Barer, D. (Newcastle upon Tyne)

213 Stroke Vignette 242 Announcement 
Contents 
No. 5

Editorial

243 Different Strokes in Different Folks: Unique Molecular Signatures of Cortical and Deep Brain Infarcts Waxman, S.G. (New HavenWest Haven, Conn.)

Original Papers

245 Glutamate Is a Marker for Cerebral Ischemia in Cortical but Not Deep Infarcts

Castillo, J. (Santiago de Compostela); Davalos, A. (Girona); Leraa, M. (Santiago de Compostela); Serena, J. (Girona); Noya, M. -(Santiago de Compostela)

251 Quality of Hospital Care for Stroke Patients in The Netherlands

van Straten, A. van der Meulen, J. H. P. van Crevel, H. (Amsterdam); Habbema, J.D.F. (Rotterdam): Limburg M. (Amsterdam)

258 Cost-of-Illness Studies of Stroke Porsdal, V.; Boysen, G. (Hvidovre)

264 The Predictive Role of 24-Hour Compared to Casual Blood Pressure Levels on Outcome following Acute Stroke Robinson, T.; Waddington, $A^{*}$;

Ward-Close, S.; Taub, N.; Potter, J. (Leicester)

273 Endovascular Treatment of Spontaneous Carotid-Cavernous

Fistula in Ehlers-Danlos SyndromeType IV. Case Report and Review of the Literature

Cesari, M.; Rossi, G.P.; Dyne, K.M. (Pavia); Fiore, D. (Padova); Pessina, A.C. (Pa via)

280 Borderzone Small Deep Infarcts. Vascular Risk Factors and

Relationship with Signs of Small-and Large-Vessel Disease Hupperts, R.M.M.; Lodder, J.; Heuts-van Raak, L.; Kessels, F. (Maastricht)

284 Misdiagnoses in 1,250 Consecutive Patients Admitted to an Acute Stroke Unit The Members of the lille Stroke Program

Meeting Report

289 Consensus Concerning the Morphology and the Risk of Carotid Plaques

de Bray. J.M.; Baud, J.M.; Dauzat, M. (Angers)

Abstracts

297 Invited Papers and Abstracts of the 'Syncope Update 1997: Treatment and Cerebral Hemodynamics' Florence, October 4,1997

263,272 Announcements 288 Erratum 
No. 6

Editorials

313 Opportunities for Collective Wisdom in Stroke Research

Moskowitz, MA. (Boston, Mass.); Dalkara, T. (Ankara) 315 What Can We Learn from Experimental Ischemia Research? Hossmann, K.-A. (Kbln)

Original Papers

318 Risk of Immediate Heparin after rt-PA Therapy in Acute Ischemic Stroke

Grand, M.; Rudolf, J.; Neveling, M.; Stenzel, C; Heiss, W.-D. (K51n)

324 The Role of Chronic Brain Edema in the Formation of Lacunes

in Binswanger's Encephalopathy. Histopathological and Immunohistochemical Observations Ma, K.-C; Olsson, Y. (Uppsala)

332 Proliferative Retinopathy Predicts Impairment in Brain Vasomotor Reserve in Type II Diabetes

Ceravolo, M.G., Lagalla, G. (Ancona); Lippera, S., Gegoin, E. (Ean Vasom); Proving

338 Early Carotid Atherosclerosis of the Internal and External Carotid Artery Related to Twenty-Four-Hour Blood Pressure Variability

Sander, D.; Klingelhofer, J. (Munich)

345 Solar and Geomagnetic Activities: Are There Associations

with Stroke Occurrence? A Population-Based Study in Siberia

Russia (1982-1992)

Feigin, V.L. (Utrecht/Novosibirsk); Nikitin, Yu. P.; Vinogradova, T.E.

(Novosibirsk)

Case Report

349 Dramatic Reversal of the Uncal Syndrome and Brain Edema from Infarction in the Middle Cerebral Artery Territory

Wijdicks, E.F.M.; Schievink, W.I.; McGough, P.F. (Rochester, Minn.)

Short Reports

353 The Paraoxonase Glutamine/Arginine Polymorphism and Cerebrovascular Disease

Lansbury, A.J.; Catto, A.J.; Carter, A.M.; Bamford, J.M.; Grant, P.J. (Leeds) 355 Hospital Admission for Recent Tl A? Ferro, J.M. (Lisboa)

Letter to the Editor

357 Non-Valvular Atrial Fibrillation in Acute Ischaemic Stroke Candidates for Thrombolytic Therapy

Yoneda, Y.; Mori, E.; Uehara, T.; Tabuchi, M. (Himeji)

Special Article

359 What Was the Reason for Joseph Haydn's Mental Decline and Gait Disturbance? A Case of Subcortical Vascular Encephalopathy in the Early 19th Century Bazner. H.A.; Hcnnerici. M.G. (Mannheim)

317 Stroke Vignette 337 Announcement

367 Author Index Vol. 7,1997

368 Subject Index Vol. 7,1997 
Suppl. 1

Update in Stroke Prevention: Problems of the Stroke Recurrence

Sanofi Winthrop Symposium to the 3rd World Stroke Congress and the 5th European Stroke Conference, Munich, Germany, September 3,1996 Editors: J. Bogousslavsky (Lausanne); JJD. East on (Providence, RX)

Suppl. 2 
Suppl. 4

Abstracts of the 6th European Stroke Conference

Amsterdam, The Netherlands, May 28-31,1997

Editor M. Hennerici (Mannheim)

\section{Suppl. 5}

\section{Progressing Stroke}

Plenary Session to the 6th European Stroke Conference,

Amsterdam, The Netherlands, May 31,1997

Editors: J. Bogousslavsky (Lausanne); M. Fisher (Worcester, Mass.)

Neuroprotective Strategies for Early Intervention in Acute Ischaem ic Stroke

Janssen-Cilag Satellite Meeting to the 3rd World Stroke

Congress and the 5th European Stroke Conference,

Munich, Germany, September 1-5,1996

Editor: W. Hacke (Heidelberg)

\section{Suppl. 3}




\section{Suppl. 6}

Update on Secondary Stroke Prevention with Antithrombotic

Drugs

Plenary Session to the 6th European Stroke Conference, Amsterdam, TheSetherlands, May 30,1997 Editors JX. Mas (Paris); P. Koudstaal (Rotterdam)

Acute Stroke Therapy. Optimal Care of the Stroke Patient

Plenary Session to the 3rd World Stroke Congress and the 5th

European Stroke Conference, Munich, Germany, September 2,

1996

Guest Editors: N.G. Wahlgren (Stockholm); T. Yamaguchi (Osaka) 
Contents 